\title{
Clinical Use of I.C.I. 50172 as an Antidysrhythmic Agent in Heart Failure
}

\author{
D. G. GIBSON,* M.A., M.B., M.R.C.P. ; R. BALCON,* M.B., M.R.C.P. ; E. SOWTON,* M.A., M.D., M.R.C.P.
}

Brit. med. F., 1968, 3, 161-163

\begin{abstract}
Cummary : I.C.I. 50172 was used to slow the ventricular rate when conventional treatment had failed in 19 patients. All were either in congestive cardiac failure or in the immediate postoperative period following valve replacement. The ventricular rate was controlled in seven out of eight patients with atrial fibrillation, in six out of nine patients with supraventricular tachycardia, and in two patients with sinus rhythm. Important side-effects were not seen.
\end{abstract}

\section{Introduction}

The beta-adrenergic receptor blocking drug propranolol has proved to be a valuable antidysrhythmic agent in the treatment of ventricular and supraventricular tachycardia (Rowlands et al., 1965). However, its use has been associated with serious hypotension, bradycardia, and the development or aggravation of congestive cardiac failure in certain cases, particularly those with impaired myocardial function (Stephen, 1966 ; Conway et al., 1968). Yet it is in such patients that a rapid ventricular rate may lead to further clinical deterioration, and a drug that could safely be used in these circumstances would have considerable therapeutic value. An intravenous injection of $5 \mathrm{mg}$.

* National Heart Hospital and Institute of Cardiology, London, W.1. of the cardio-selective beta-adrenergic blocking drug I.C.I. 50172 has been shown to reduce the heart rate, both at rest and during continuous exercise, without a drop in cardiac output (Gibson and Sowton, 1968 ; Sowton et al., 1968). A clinical trial to assess its possible value in controlling rapid ventricular rates in patients with impaired myocardial function was therefore carried out.

\section{Material and Methods}

The drug was administered to 19 patients. Eight were in severe congestive cardiac failure with pulmonary oedema, and 11 were in the immediate postoperative period after mitral or aortic valve replacement. The clinical details are given in Tables I and II. In all cases other antidysrhythmic agents or D.C. shock had been used according to the usual clinical indications and had been ineffective. All the patients had a ventricular rate of $140 / \mathrm{min}$. or more at the time that the I.C.I. 50172 was given, and the drug was used only when rapid control of the ventricular rate appeared essential.

An intravenous injection of $5 \mathrm{mg}$. was given initially, followed by further doses of $5 \mathrm{mg}$. at intervals of one to two minutes if necessary until a total of $25 \mathrm{mg}$. had been reached. The E.C.G. was monitored throughout, and the systemic arterial pressure was measured between each injection. In

Table I.-Group 1. Postoperative Patients

\begin{tabular}{|c|c|c|c|c|c|c|c|c|c|}
\hline \multirow{2}{*}{$\begin{array}{l}\text { Case } \\
\text { No. }\end{array}$} & \multirow{2}{*}{ Operation } & \multicolumn{2}{|c|}{ Dysrhythmia } & \multicolumn{2}{|c|}{ Heart Rate (Beats/min.) } & \multicolumn{2}{|c|}{ Blood Pressure (mm. Hg) } & \multirow{2}{*}{$\begin{array}{l}\text { Dose } \\
\text { (mg.) }\end{array}$} & \multirow{2}{*}{$\begin{array}{l}\text { Treatment } \\
\text { Before } \\
\text { I.C.I. } 50172\end{array}$} \\
\hline & & $\mathbf{A}$ & B & $\mathbf{A}$ & B & $\mathbf{A}$ & $\bar{B}$ & & \\
\hline $\begin{array}{l}1 \\
2 \\
3 \\
4 \\
5 \\
6\end{array}$ & $\begin{array}{l}\text { Aortic Starr } \\
\text { Aortic and mitral Starrs } \\
\text { Mitral Starr } \\
\text { Aortic and mitral Starrs } \\
\text { Aortic homograft } \\
\text { Aortic Starr, Vineberg }\end{array}$ & $\begin{array}{l}\text { AF } \\
\text { SVT } \\
\text { AF } \\
\text { SVT } \\
\text { SVT }\end{array}$ & $\begin{array}{c}\mathrm{AF} \\
\mathrm{SVT} \\
\mathrm{AF} \\
\mathrm{Nodal} \\
\mathrm{SR} \\
\mathrm{SVT}\end{array}$ & $\begin{array}{l}160 \\
240 \\
145 \\
160 \\
150 \\
180\end{array}$ & $\begin{array}{r}85 \\
160 \\
110 \\
78 \\
110 \\
100\end{array}$ & $\begin{array}{r}130 / 90 \\
80 / 65 \\
110 / 50 \\
100 / 70 \\
140 / 90 \\
90 / 60\end{array}$ & $\begin{array}{l}140 / 80 \\
110 / 70 \\
110 / 50 \\
100 / 70 \\
120 / 90 \\
120 / 80\end{array}$ & $\begin{array}{l}5 \\
5 \\
5 \\
5 \\
5 \\
3\end{array}$ & $\begin{array}{l}\text { Digoxin } \\
\text { Digoxin, lignocaine* } \\
\text { Digoxin, lignocaine } \\
\text { Digoxin, lignocaine } \\
\text { Digoxin } \\
\text { Digoxin, lignocaine, }\end{array}$ \\
\hline 8 & $\begin{array}{l}\text { Aortic and mitral Starrs } \\
\text { Tricuspid Start, mitral } \\
\text { valvotomy }\end{array}$ & $\begin{array}{l}\text { SVTT } \\
\text { SVT }\end{array}$ & $\begin{array}{l}\text { SVT } \\
\text { SR }\end{array}$ & $\begin{array}{l}220 \\
180\end{array}$ & $\begin{array}{r}220 \\
90\end{array}$ & $\begin{array}{l}115 / 80 \\
100 / 70\end{array}$ & $\begin{array}{l}105 / 80 \\
110 / 70\end{array}$ & $\begin{array}{r}20 \\
8\end{array}$ & $\begin{array}{l}\text { Digoxin, lignocaine } \\
\text { Digoxin, lignocaine, pro } \\
\text { cainamide, D.C. shock }\end{array}$ \\
\hline 11 & Aortic and mitral Starrs & $\mathbf{A F}$ & & 160 & 100 & $100 / 60$ & $120 / 80$ & 5 & Digoxin, lignocaine \\
\hline
\end{tabular}

$A=$ Before I.C.I. 50172. B = After I.C.I. 50172. AF = Atrial fibrillation. SVT = Supraventricular tachycardia. SR $=$ Sinus rhythm. Starr $=$ Starr-Edwards prosthesis. - Later reverted to sinus thythm after D.C. shock.

TABLE II.-Group 2. Patients in Congestive Heart Failure

\begin{tabular}{|c|c|c|c|c|c|c|c|c|c|}
\hline \multirow{2}{*}{$\begin{array}{l}\text { Case } \\
\text { No. }\end{array}$} & \multirow{2}{*}{ Clinical Details } & \multicolumn{2}{|c|}{ Dyschythmia } & \multicolumn{2}{|c|}{ Heart Rate (Beats/min.) } & \multicolumn{2}{|c|}{ Blood Pressure (mm. Hg) } & \multirow{2}{*}{$\begin{array}{l}\text { Dose } \\
\text { (mg.) }\end{array}$} & \multirow{2}{*}{$\begin{array}{c}\text { Treatment } \\
\text { Before } \\
\text { I.C.I. } 50172\end{array}$} \\
\hline & & $\mathbf{A}$ & B & $\mathbf{A}$ & B & $\mathbf{A}$ & B & & \\
\hline 12 & Mired mitral valve disease. & $A R$ & $A R$ & 170 & 110 & 9170 & $10=160$ & 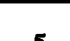 & \\
\hline 13 & Aschate puimonary heart disease. Severe & $\mathbf{S F}$ & sa & 170 & 110 & $90 / 70$ & $105 / 00$ & 3 & \\
\hline 14 & $\begin{array}{l}\text { Conpestive heart failure } \\
\text { Mitral and aortic valve discase. }\end{array}$ & $\mathbf{A F}$ & $\mathbf{A F}$ & 160 & 92 & $110 / 70$ & 100/70 & 25 & Digoxin \\
\hline 15 & $\begin{array}{l}\text { Intractable heart failure } \\
\text { Myocardial infarction. Recent }\end{array}$ & SR & SR & 140 & 95 & $110 / 70$ & $110 / 80$ & 5 & Digoxin \\
\hline 16 & monary oedema & SVT & SR & 200 & 120 & $100 / 70$ & $110 / 80$ & 10 & Digoxin, lignocaine \\
\hline 17 & geative heart failure & $\mathbf{A F}$ & $\mathbf{A F}$ & 140 & 90 & $110 / 70$ & $110 / 80$ & 5 & Digoxin \\
\hline 18 & monary oedema & SVT & SVT & 200 & 200 & 90/? & 90/2 & 15 & $\begin{array}{l}\text { D.C. shock, dicoxin, lig" } \\
\text { nocaine, procainamides }\end{array}$ \\
\hline 18 & Myocardial infarction. Ruptured & SR & SR & 140 & 100 & $60 / ?$ & $80 / ?$ & 5 & cing \\
\hline 19 & $\begin{array}{l}\text { Ischaemic heart disease. Severe } \\
\text { congestive heart failure }\end{array}$ & $\mathbf{A P}$ & $\mathbf{A F}$ & 140 & 140 & $150 / 90$ & $150 / 100$ & 5 & \\
\hline
\end{tabular}


three cases a single intravenous dose was effective for only 30 to 60 minutes, and in these an intravenous infusion containing $20 \mathrm{mg}$. was given over 24 hours.

\section{Results}

Atrial Fibrillation.-Eight patients in atrial fibrillation were treated, and the rate was controlled in seven. In the eighth (Case 19) a dose of only $5 \mathrm{mg}$. was used, and it is possible that a larger dose would have been effective. All the patients had been treated with digitalis, and in two (Cases 13 and 16) with intractable heart failure it had been given to the limit of tolerance. In both of these patients slowing of the heart rate was accompanied by renewed sensitivity to diuretics.

Other Supraventricular Tachycardias.-The drug was given to nine patients, seven of whom were in the immediate post-

Before.

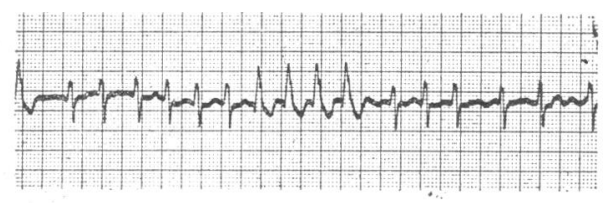

BP $\frac{130}{90}$

$5 \mathrm{mg} .1 \mathrm{Cl} 50172$

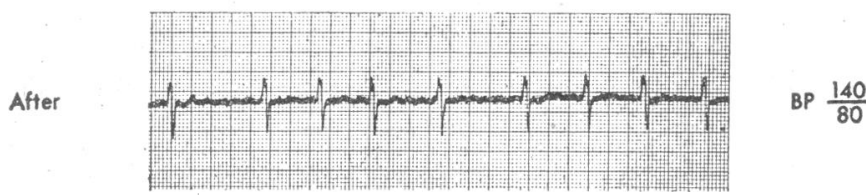

FIG. 1.-Case 1. Heart rate of $160 / \mathrm{min}$. due to atrial fibrillation with many aberrated complexes was reduced to $85 / \mathrm{min}$. by $5 \mathrm{mg}$. of I.C.I.
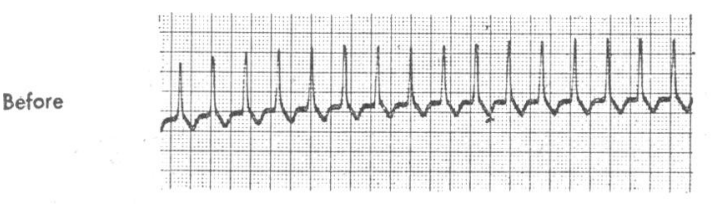

\section{$3 \mathrm{mg}, \mathrm{ICl} 50172$}

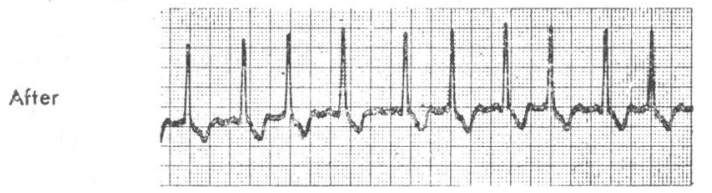

BP $\frac{120}{80}$

FIG. 2.-Case 6. Heart Rate of $180 / \mathrm{min}$. due to supraventricular tachycardia was slowed to $90 / \mathrm{min}$. with the development of $3: 1$ and $4: 1$ atrioventricular block.

\section{Before}

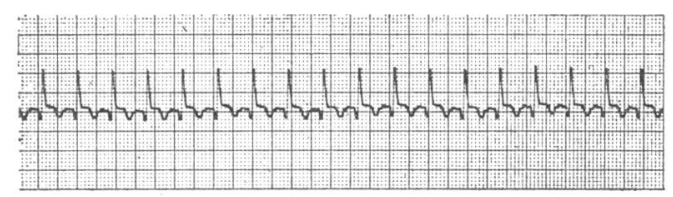

BP $\frac{100}{70}$

$8 \mathrm{mg} \cdot \mathrm{ICl} 50172$

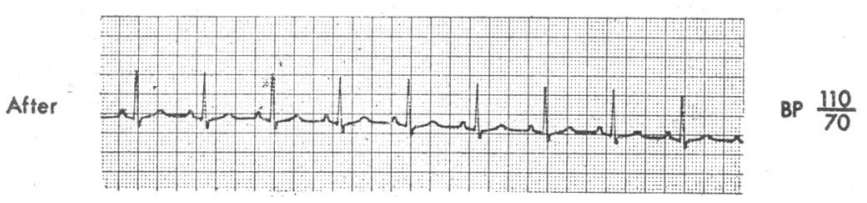

FIG. 3.-Case 8. Heart rate of $180 / \mathrm{min}$. due to supraventricular tachycardia was slowed to $90 / \mathrm{min}$., with conversion to normal sinus rhythm. operative period. The heart rate was reduced to less than 120 / min. in six and was only partially controlled in another one (Case 2). In two cases the rate was unaffected by the drug; one of these (Case 7) subsequently responded to D.C. shock, while in the other (Case 17) the rate was not controlled by D.C. shock, paired pacing of the atria, or surgical division of the bundle of His. Of the cases that responded to the drug three were converted to sinus rhythm with a normal $P-R$ interval and four developed an increased degree of atrioventricular block.

Sinus Rhythm.-Two cases were in sinus rhythm, and in both the rate was slowed. The P-R interval remained unaltered.

Representative electrocardiograms are reproduced in Figs. 1-3.

Side-effects. - There appeared to be no significant side-effects attributable to the drug in the doses used. In particular, undue hypotension and bradycardia did not occur, and the clinical features of heart failure were not aggravated.

\section{Discussion}

The present series of patients was highly selected, since all cases were considered to have impaired myocardial function, either because they were in the immediate postoperative period following valve replacement or because they were in severe congestive cardiac failure. In addition, all the patients had been treated with other antidysrhythmic agents or with D.C. shock without effect. Propranolol was contraindicated in this group because of the risk of severe depression of left ventricular function and was not used. In these patients I.C.I. 50172 proved a safe and effective method of controlling the ventricular rate. Reversion to sinus rhythm occurred in three patients and reduction in the heart rate was seen in a further 13, usually accompanied by clinical improvement.

I.C.I. 50172 appeared to have particular value in the treatment of supraventricular tachycardia in the immediate postoperative period; it was frequently effective, and was active within one to two minutes of injection. Even when the dysrhythmia was not controlled, as in Case 7, no untoward effects were produced. Though postoperative supraventricular tachycardia can often be controlled by digitalis, the drug must be used with caution, since the difference between a therapeutic and a toxic dose may be small and the consequences of overdose serious, particularly in the presence of renal failure or hypokalaemia. Furthermore, there may be diagnostic difficulties about whether the dysrhythmia itself is due to digitalis overdose, so that large doses cannot be given, and rapid control of the ventricular rate is not usually possible. In addition, digitalis may be withheld from fear of prejudicing the success of subsequent attempted D.C. shock. Even when digitalis is used it may fail to control the tachycardia, and the patients reported here represent 10 such cases.

Side-effects were not common. A slight drop in systolic arterial pressure, which appeared to have no clinical significance, occurred in four patients; the maximum fall was $20 \mathrm{~mm}$. $\mathrm{Hg}$, from 140 to $120 \mathrm{~mm}$. Hg. One patient (Case 18) with a massive cardiac infarction and ruptured interventricular septum died within a few hours of receiving I.C.I. 50172. In view of the severity of the lesion, and the fact that his systolic arterial pressure increased from 60 to $80 \mathrm{~mm}$. Hg after I.C.I. 50172, it was not felt that the drug had contributed to his death. In no case were the clinical manifestations of heart failure aggravated, and undue bradycardia did not occur. The $\mathrm{P}-\mathrm{R}$ interval of those cases in sinus rhythm after the drug remained normal.

The results of I.C.I. 50172 administration in the present series of patients correlate with pharmacological studies, showing significant differences from propranolol. Unlike propranolol, I.C.I. 50172 has a weak sympathomimetic action 
demonstrable in the adrenalectomized preparation treated with reserpine and atropine (Barrett et al., 1967). In addition, it lacks the quinidine-like and local anaesthetic actions of propranolol, and it is not a direct depressant of myocardial function (Barrett et al., 1967). I.C.I. 50172 has activity equal to propranolol in blocking the cardiac inotropic and chronotropic effects of stellate ganglion stimulation, but it has only one-third that in blocking the effects of isoprenaline on the heart (Barrett et al., 1967). When given to normal subjects during continuous submaximal exercise, $5 \mathrm{mg}$. of I.C.I. 50172 causes a drop in heart rate, with no change in cardiac output (Gibson and Sowton, 1968), in contrast to the reduction seen after $5 \mathrm{mg}$. of propranolol (Epstein et al., 1965). A similar effect is seen at rest in patients with ischaemic heart disease given I.C.I. 50172 where, in addition, an increase in the mean systolic ejection rate can be shown, suggesting a positive inotropic effect (Sowton et al., 1968).

It was of interest that a drug such as I.C.I. 50172, lacking local anaesthetic and quinidine-like properties, should show any antidysrhythmic activity. In patients with sinus rhythm, slowing of the heart rate is presumably brought about by a direct action in the sino-atrial node. The increase in the degree of block that occurred in the patients with atrial tachycardia, and the slowing of the ventricular rate in atrial fibrillation, both suggest an additional action on the atrioventricular node. These are both sites of action of sympathetic stimulation and of exogenous isoprenaline (Linhart et al., 1965). Patients with congestive cardiac failure have increased basal sympathetic tone (Gaffney and Braunwald, 1963), and it may be that this was a factor in the initiation or maintenance of the arrhythmias in the present series of patients. It is possible that in some patients
I.C.I. 50172 may have allowed other antidysrhythmic drugs given previously to become effective by virtue of its action in blocking this cardiac sympathetic tone.

I.C.I. 50172 therefore appears to be a useful agent for slowing the heart in the doses we used. Its action is rapid in onset, and side-effects are not prominent, even in seriously ill patients. The presence of impaired myocardial function has proved not to be a contraindication to its use, and in such patients it may well be superior to propranolol. On theoretical grounds it is unlikely to be effective in those dysrhythmias where a drug with local anaesthetic or quinidine-like properties is required, but it nevertheless appears to be worthy of further clinical trial.

We would like to thank our colleagues for permission to publish details of their cases, and Dr. Desmond Fitzgerald, of Imperial Chemical Industries, for supplies of I.C.I. 50172.

\section{RBPERENCES}

Barrett, M., et al. (1967). Cardioselective Beta Blockade : Pharmacological Studies with I.C.I. 50172 . Macclesfield.

Conway, N., Seymour, J., and Gelson, A. (1968). Brit. med. Y., 2, 213. Epstein, S. E., Robinson, B. F., Kahler, R. L., and Braunwald, E. (1965). 7. clin. Invest., 44,1745 .

Gaffney, T. E., and Braunwald, E. (1963). Amer. F. Med., 34, 320.

Gibson, D., and Sowton, E. (1968). Brit. med. Y., 1, 213.

Linhart, J. W., Braunwald, E., and Ross, J. (1965). \%. clin. Invest., 44, 883.

Rowlands, D. J., Howitt, G., and Markman, P. (1965). Brit. med. Y., 1, 891.

Sowton, E., Balcon, R., Cross, D., and Frick, H. (1968). Brit. med. Y.,

Stephen, S. A. (1966). Amer. F. Cardiol., 18, 463.

\section{Preliminary Communications}

\section{High Haemoglobin Values During Medical Treatment of Hypertension}

Brit. med. F., 1968, 3, 163-165

\begin{abstract}
cummary : In 123 patients with arterial hypertension the $\$$ haemoglobin values were determined before and during long-term antihypertensive drug treatment. The haemoglobin values found before treatment did not differ from those found in the normal population. In both sexes the haemoglobin values showed a significant increase after prolonged treatment. In males the average values rose from 15.1 to $16.7 \mathrm{~g} . / 100 \mathrm{ml}$., and in females from 13.96 to $14.82 \mathrm{~g} . / 100 \mathrm{ml}$. The increase in the haemoglobin concentration does not seem to be clearly correlated to the duration of treatment or to the decrease produced in mean blood pressure. On the other hand, the increase in haemoglobin depended to some extent on the nature of treatment. Diuretics alone resulted in a moderate increase only, whereas diuretics in combination with other antihypertensive drugs produced a more pronounced increase in haemoglobin values.
\end{abstract}

\section{INTRODUCTION}

During recent years we on several occasions observed remarkably high haemoglobin values in hypertensive subjects treated in our outpatient clinic. We therefore decided to make a survey of all patients seen by us over the past nine years, with the object of comparing the haemoglobin values before treatment with the last values measured during treatment.

\section{Material and Methods}

Of the 184 patients treated, the following were excluded from the present investigation: (1) 42 who at the beginning of the study were being treated or had recently been treated with hypotensive drugs ; (2) 11 suffering from bleeding from various sites, or with severe medical disorders which might influence the haemoglobin value; and (3) eight with serum creatinine values equal to or above $3 \mathrm{mg} . / 100 \mathrm{ml}$; this limit was chosen on the basis of recent investigations (Hilden and Hilden, 1968) which showed that in hypertensive outpatients the renal funetion has to be severely impaired before renal anaemia occurs. Thus 61 patients had to be excluded. Of the remaining 123 71 were males and 52 females.

Of the 71 males two had chronic glomerulonephritis and 69 had essential hypertension. Of the 52 females 8 had chronic pyelonephritis, 2 had surgically treated renal arterial stenosis, and 42 had essential hypertension.

All were treated as outpatients, and most of them continued their usual occupation. None suffered from heart failure or oedema. The age, systolic and diastolic blood pressure, eye background changes, and serum creatinine level are shown in 